\title{
Major Salivary Gland Cancer cM1 TNM Finding v7
}

National Cancer Institute

\section{Source}

National Cancer Institute. Major Salivary Gland Cancer cM1 TNM Finding v7. NCI

Thesaurus. Code C89128.

Major salivary gland cancer with distant metastasis. (from AJCC 7th Ed.) 